\title{
KONSEP KEBEBASAN DALAM ISLAM
}

\author{
Oleh : Muh. In'amuzzahidin
}

Fakultas Ushuluddin dan Humaniora Universitas Negeri Islam Walisongo Email:m.inamuzzahidin@yahoo.co.id

\begin{abstract}
Abstrak :

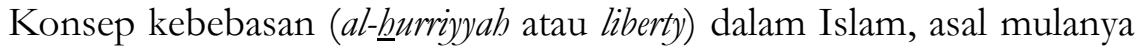
adalah konsep ikhtiyar dan taqdir, yang berkaitan dengan kebebasan atau tidaknya manusia dalam melakukan perbuatannya, dalam term teologi atau agama. Kemudian setelah terjadinya kontak dengan dunia barat konsep tersebut berkembang menjadi lebih luas cakupannya. Seperti kebebasan berekspresi atau mengemukakan pendapat, berfikir, kebebasan berpolitik atau kebebasan ekonomi. Dalam tulisan ini, penulis akan membahas lebebasan berfikir dan mengemukakan pendapat; kebebasan beragama; kebebasan berpolitik, meliputi hak memilih pemimpin, hak mengawasi dan mengontrol pemerintah; dan kebebasan ekonomi. Kebebasan dalam Islam lebih terbatas dan terarah, atau dengan kata lain bebas tapi terikat. Berbeda dengan demokrasi liberal menekankan kemampuan berbuat tanpa batas.
\end{abstract}

Kata Kunci : kebebasan; hurriyyah; liberalisme; demokrasi; politik.

\section{A. Pendahuluan}

Manusia, yang mempunyai potensi kebaikan dan kejahatan, telah diberi kebebasan penuh oleh Allah untuk memilihnya, dengan segala konsekuensi di dunia dan di akhirat kelak. Sejalan dengan itu, Allah menciptakan akal baginya untuk mengidentifikasi kedua hal tersebut. ${ }^{1}$

Hal di atas dapat diihat dalam al-Qur'an, secara eksplisit maupun implisit, ${ }^{2}$ yang membicarakan tentang kebebasan manusia untuk menentukan sendiri perbuatannya yang bersifat ikhtiyariyyah. Yakni perbuatan yang dinisbatkan kepada manusia dan menjadi tanggung jawabnya, karena kemampuan yang dimilikinya untuk melakukan atau meninggalkannya. ${ }^{3}$ Dalam perkembangan selanjutnya, setelah Islam

\footnotetext{
1 Abd al-Mutaal as-Saidi (selanjutnya disebut as-Saidi), Kebebasan Berpikir dalam Islam, (Hurriyyat al-Fikr Fî al-Islâm), terj. Ibnu Burdah, Adi Wacana, Yogyakarta, cet. I, 1999, hlm. 7-9

${ }^{2}$ Misalnya, QS. al-Insan / 76 : 3; QS. al-Balad / 90 : 10; QS. al-Kahfi / 18 : 29; QS. alMudatstsir / 74 : 35-37

${ }^{3}$ Machasin, Menyelami Kebebasan Manusia, Pustaka Pelajar, Yogyakarta, cet. I, 1996, hlm. 30-31
} 
mengalami kontak dengan barat, term kebebasan, tidak hanya menyangkut persoalan teologi (ikbtiyâr atau taqdîr), tetapi juga mencakup kebebasan ekspresi, ekonomi ataupun kebebasan berpolitik.

Oleh karenanya berbicara masalah kebebasan, yang oleh Norman P. Barry, diartikan sebagai "tidak adanya suatu paksaan atau rintangan", dan oleh Werner Becker didefinisikan sebagai "orang yang dalam batas-batas tertentu dapat melakukan atau meninggalkan apa yang dia inginkan", ${ }^{4}$ tidak bisa terlepas dengan konteks demokrasi, teologi, pemikiran, politik ataupun sikap dalam (menentukan) agama. Tulisan ini akan mencoba melihat kebebasan dalam Islam yang meliputi kebebasan berpikir, kebebasan beragama, kebebasan ilmiah, kebebasan politik, dan kebebasan ekonomi, dengan membandingkannya pada konsepsi kebebasan di luar Islam.

\section{B. Kebebasan di Luar Islam}

Kebebasan, yang merupakan salah satu unsur demokrasi, ${ }^{5}$ tidak selamanya diperoleh oleh setiap manusia, walaupun itu adalah hak masingmasing individu. Hal tersebut dapat dilihat dalam 'syari'at' di luar Islam. Dimana kebebasan sipil, yakni status yang membuat seseorang bebas melakukan berbagai transaksi, memikul beban, memiliki harta bergerak atau tidak bergerak dan mengelola harta miliknya, ${ }^{6}$ terkadang dikebiri habishabisan.

\footnotetext{
${ }^{4}$ Sebagaimana dikutip dari Masykuri Abdillah, Demokrasi di Persimpangan Makna : Respons Intelektual Muslim Indonesia terbadap Konsep Demokrasi, (Responses of Indonesian Muslim Intellectuals to the concept of Demokracy) (1966-1993), terj. Wahib Wahab, Tiara Wacana, Yogya, cet. I, 1999, hlm. 134; Masykuri Abdillah, Theological Responses to the Concept of Democracy and Human Rights: The Case of Contemporary Indonesia Muslim Intellectuals, Studia Islamika, Vol. 3, No. 1, IAIN Syarif Hidayatullah, Jakarta, 1996, hlm. 8-9; Sejalan dengan definisi di atas, Franz Magnis Suseno juga mengatakan bahwa : kebebasan adalah tidak adanya paksaan dari orang lain untuk melakukan sesuatu yang melawan kehendak kita, atau adanya kemampuan menentukan diri sendiri. Menurutnya arti kebebasan dapat dibedakan menjadi dua arti. Pertama kebebasan social. Yakni kebebasan yang kita terima dari orang lain. Ke dua kebebasan eksistensial. Yaitu kemampuan kita untuk menentukan tindakan kita sendiri. Franz Magnis Suseno, Etika Dasar, Kanisius, Yogyakarta, cet. VII, 1997, hlm. 22

5 Demokrasi merupakan proses pembebasan dari segala bentuk diskriminasi dan kesewenang-wenanngan. Disamping ada kebebasan, juga ada persamaan, keadilan dan musyawarah. Lebih lanjut lihat Franz Magnis Suseno, Demokrasi Sebagai Proses Pembebasan: Tinjauan Filoofis dan Historis, dalam Agama dan Demokrasi, P3M bekerjasama dengan Friedrich Nauman Stiftung (FNS), Jakarta, cet. I, 1992, hlm. 7; Abdurrahman Wahid, Sosialisasi Nilai- Nilai Demokrasi, dalam Agama, Demokrasi dan Trasformasi Sosial, Edit. M. Masyhur Amin dan Mohammad Najib, LPKSM NU DIY, Yogyakarta, cet. I, 1993, hlm. 89

${ }^{6}$ Ali Abdul Wahid Wafi (selanjutnya disebut Wafi), Kebebasan Dalam Islam (al-Hurriyat Fi al-Islâm), terj. H. S. Agil Husin al-Munawar, dan Lukman Hakim Zainuddin, Dina Utama
} 
'Syari'at' Hindu Brahma misalnya, tidak menganggap hak-hak sipil kasta sudra, yang disejajarkan dengan budak. Padahal mereka juga termasuk golongan bangsa sendiri. Karena mereka dianggap kotor dan najis, yang tidak pantas untuk digauli, kecuali dengan budak.

Demikian juga bangsa Yunani kuno. Bangsa ini tidak mengakui eksistensi hak sipil bagi orang yang tidak berbangsa Yunani kuno. Karena mereka berkeyakinan, bahwa merekalah yang paling sempurna kemanusiaannya, yang dibekali kekuatan akal dan kemauan, yang membedakan dengan binatang. Tidak hanya itu, undang-undang mereka pun dalam menempatkan posisi wanita sangat diskriminatif. Karena wanita adalah harta bagi walinya, saat belum berkeluarga. ${ }^{7}$

Hal serupa juga berlaku di kalangan bangsa Romawi kuna. Dimana undang-undang dan sistem sosialnya membuat selain bangsa Romawi tidak memperoleh semua atau sebagaian besar hak sipilnya. Mereka memandang bangsa lain sebagai golongan yang hina, dan dianggap sebagai budak mereka. Aturan Yahudi juga tidak mengakui hak sipil yang sempurna bagi selain bangsa Israel. Karena menurut mereka, hanya merekalah bangsa yang terpilih, dan yang lain adalah budak bagi mereka. ${ }^{8}$

Kemudian jika kita melihat konsep kebebasan ala barat, setidaknya ada dua kata yang cukup representatif untuk itu. Yakni freedom dan liberty, yang pengertiannya juga tidak jauh berbeda dengan apa yang telah kami abstraksikan di atas. Dimana konsep interpersonal atau social freedom menunjukkan pada hubungan interaktif antara person atau kelompok, dimana antara satu dengan yang lain memberikan kebebasan untuk melakukan sesuatu dalam berbagai bentuk cara. ${ }^{9}$

Pada mulanya, liberalisme identik dengan partai politik atau kelas social dan program spesifik. Namun sekarang istilah tersebut digunakan pada sebuah system pemikiran dan perbuatan, yang tidak spesifik pada doktrin filsafat, dan lebih inklusif dari pada prinsip partai.

Semarang (Toha Putra Group), t.th, hlm. 7; Senada dengan definisi di atas, H. A.M. Saefuddin menyatakan bahwa kebebasan perorangan adalah kebebasan bagi tiap individu dalam perjalanannya, terpeliharanya dari segala bentuk penganiayaan, dan larangan menangkap, menyiksa atau memenjarakan kecuali dengan tuntunan hukum, serta kebebasannya untuk berimigarasi ke luar masuk negara. A.M. Saefuddin, Ijtibad Politik Cendikiawan Muslim, Gema Insani Press, Jakarta, cet. I, 1996, hlm. 10

${ }^{7}$ Wafi, ibid., hlm. 10, 12

${ }^{8}$ Wafi, ibid., hlm. 11-12

9 International Encyclopedia of the Social Sciences, The Macmillan Company and The Free Press, New York, Collier - Macmillan Publishers, London, 1972, Vol. 3 and 4, hlm. 554555 
Liberalisme setidaknya dapat dideskripsikan dengan 1) adanya nilai kebebasan berekspresi dari personalitas individual; 2) adanya kepercayaan terhadap kemampuan manusia untuk membuat ekspresi tersebut bagi mereka sendiri dan masyarakat; 3) penegakan dari institusi-institusi dan kebijakan-kebijakannya, yang menjaga dan membantu adanya kebebasan ekspresi dan kepercayaan terhadap kebebasan. ${ }^{10}$

Pemikiran dan perbuatan liberal menekankan dua hal utama. Pertama tidak suka kesewenang-wenangan dari otoritas tertentu. Ke dua adanya kebebasan ekspresi dari masing-masing individu. Maka setiap perbuatan atau pemikiran bebas, setidaknya memuat salah satu dua unsur tersebut. Dari sinilah muncul tuntunan kebebasan kata hati dan toleransi beragama. Pengikut liberalisme sering tidak konformis dalam agama, para sekularis dan bahkan anti agama. ${ }^{11}$ Karena liberalisme sangat menekankan adanya kebebasan tersebut. Disamping itu, mereka juga tidak sepakat adanya intervensi penguasa (negara) dalam masyarakat untuk mendapatkan persamaan dan kesempatan, baik yang berkaitan dengan ekonomi atau persoalan social. ${ }^{12}$

\section{Kebebasan Dalam Islam}

Berbicara tentang kebebasan dalam Islam, menurut penulis, adalah sangat komplek, tergantung dari sudut mana kita memandang. Dari tasawuf misalnya. Kebebasan dapat diartikan dengan terbebasnya seseorang dari dominasi dan jebakan materi-kebendaan. Dengan dzawq-nya, ia mampu menyaksikan hakekat kebenaran (mukâsyafah/ ketersingkapan). ${ }^{13}$ Atau dari teologi Islam, seseorang akan mendapatkan bahasan tentang kebebasan berkehendak (free will anda free act) sebagai lawan dari predestinasi (taqdir), sebagaimana yang tampak dalam perdebatan antara golongan mu'tarilah, jabariyyah dan sunni dengan berbagai argumentasinya. ${ }^{14}$ Namun kebebasan

${ }^{10}$ Ibid., vol. 9 and 10, hlm. 276
${ }^{11}$ Loc. cit.
${ }^{12}$ Ibid., hlm. 277
${ }^{13}$ Abdul Munir Mulkhan, Mencari Tuban dan Tujuh Jalan Kebebasan (Sebuah Esai Pemikiran Imam al-Ghazali), Bumi Akasara, Jakarta, cet. I, 1992, hlm. 122

${ }^{14}$ Menurut golongan mu'tazilah, manusia mempunyai kemerdekaan dan kebebasan dalam menentukan perjalanan hidupnya. Sebaliknya golongan jabariyyah menganggap manusia tidak mempunyai kemerdekaan dalam menentukan kehendak dan perbuatannya. Karena semua perbuatannya adalah ditentukan oleh Allah semata. Sedangkan sunni mengkombinasikan kedua pemikiran tersebut, seraya mengatakan bahwa semua tindakan manusia adalah dari Allah, namun manusia mempunyai bagian dalam mewujudkannya (atau yang disebut dengan kasb). Lihat W. Montgomery Watt, Islamic Philosophy and Theology, Edinburgh University Press, Amerika, 1979, hlm. 87-88; H.A.R. Gibb, et. al., The 
yang akan penulis bicarakan adalah dalam konteks pemikiran keagamaan dan politik.

Jika kembali ke masa silam, dimana Nabi dan kaum Muhajirin dan Anshar mengadakan perjanjian tertulis dengan orang-orang yahudi, yang tertuang dalam piagam Madinah, secara eksplisit atau implicit, sudah ada nilainilai kebebasannya. ${ }^{15}$ Secara general, kebebasan dalam Islam sangat banyak sekali. Menurut syekh Musthafâ al-Ghalâyanî, kebebasan itu mencakup kebebasan individual, kebebasan social, kebebasan ekonomi dan kebebasan berpolitik. Dimana kebebasan individu sendiri mencakup kebebasan berpendapat, menulis dan mencetaknya, dan kebebasan berfikir sekaligus penyebarannya. ${ }^{16}$ Namun menurut hemat penulis, kebebasan individu tersebut cukup diwakili oleh kebebasan berfikir dan mengemukakan pendapat. Sebab kebebasan menulis atau kebebasan menyebarkan pemikiran sudah masuk di dalamnya. Oleh karenanya, penulis akan mencoba mengungkapkan beberapa kebebasan itu, yang berkaitan dengan kegiatan intelektual, keagamaan, ekonomi, dan perpolitikan.

\section{C.1. Kebebasan Berfikir dan Mengemukakan Pendapat}

Dalam Islam, kebebasan berfikir dan berpendapat sangat dihargai. Hal ini dapat dilihat dari perjalanan historis Islam awal pada zaman Nabi dan sahabatnya, ${ }^{17}$ atau dari ajaran-ajaran Islam itu sendiri, yang akan

Encyclopaedia of Islam, E.J. Brill, Leiden, 1960, hlm. 696; Harun Nasution, Teologi Islam, UIPress, Jakarta, cet. V, 1986, hlm. 31, 70; Masykuri Abdillah, Demokrasi, op. cit., hlm. 137; Machasin, op. cit., hlm. 124-130

15 Dalam Piagam Madinah juga menyebutkan prinsip kebebasan. Diantaranya adalah kebebasan melakukan adat kebiasaan yang baik, kebebasan dari kekurangan, kebebasan dari penganiayaan dan menuntut hak, kebebasan dari rasa takut, dan kebebasan berpendapat. Muhammad Husain Haekal, Sejarah Hidup Muhammad, (Hayat Muhammad) terj. Ali Audah, Litera Antar Nusa, Jakarta, cet. XVI, 1992, hlm. 199-205; J. Suyuthi Pulungan, PrinsipPrinsip Pemerintahan Dalam Piagam Madinah ditinjau dari Pandangan al-Qur'an, Raja Grafindo Persada, Jakarta, cet. II, 1996, hlm. 156-167

${ }^{16}$ Kebebasan (al-hurriyyah) menurut al-Ghalâyanî, berasal dari kata al-hur, yang berarti terbebas dan merdeka dari perbudakan, sekaligus bebas menentukan pilihannya. Namun bebas di sini bukan berarti bebas sebebasnya, tanpa memperhatikan hukum yang berlaku, atau bahkan melanggar ajaran-ajaran agama. Syekh Musthafâ al-Ghalâyanî, Tdhah al-Nâsyi în Kitâb akblâq wa adâb wa Ijtimât', Maktabah Raja Murah Pekalongan, Pekalongan, t.t., hlm. 86, 88,90

${ }_{17}$ Menurut catatan sejarah Islam permulaan terdapat bukti-bukti yang menunjukkan bahwa Nabi memberikan kebebasan kapada para sahabatnya untuk berbicara dan mengemukakan pendapat mereka. Hal ini tampak dalam musyawarah-musyawarah atau konsultasi yang beliau laksanakan untuk membahas berbagai persoalan atau pemberian kelonggaran kepada mereka untuk menentukan pilahan. Selama perang Uhud misalnya, ketika Rasulullah meminta para sahabat untuk melawan musuh di dalam kota Madinah, 
penulis bahas lebih lanjut. Sedang yang dimaksud dengan kebebasan berpikir dan mengemukakan pendapat adalah adanya kebebasan masingmasing individu untuk berfikir secara mandiri tentang segala sesuatu yang ada di sekelilingnya, fenomena yang terlintas dalam pikirannya dan berpegang pada hasil pemikirannya, serta mengemukakannya dengan berbagai bentuk cara. ${ }^{18}$

Kemudian kebebasan berpikir mencakup kebebasan berilmu dan kebebasan berpikir ilmiah. Artinya setiap orang berhak menetapkan pemikirannya mengenai fenomena cakrawala, alam, binatang, tumbuhtumbuhan, manusia, dan berpegang pada hasil pemikirannya serta mengemukakannya. Dalam Islam sendiri tidak menetapkan rumusan atau teori ilmiah tertentu mengenai fenomena-fenomena tersebut. Karena itulah, al-Qur'an dalam hal ini hanya menganjurkan kepada akal manusia, agar memikirkan setiap fenomena alam, dan memberi motivasi untuk selalu merenungkan, dan menggali beberapa aturan umumnya, sebagai upaya riset,${ }^{19}$ disamping sebagai jalan utama menuju iman dan Islam. ${ }^{20}$ Dan ayat-ayat al-Qur'an yang menekankan manusia agar merenungkan fenomena yang ada di sekitarnya sangat beragam. Diantaranya adalah QS. al-A'raf : 185, QS. al-Baqarah: 164, QS. al-Nur: 43-44, yang mengisaratkan

mereka bertanya kepada beliau mengenai posisi beliau, berkaitan dengan pendapat yang beliau kemukakan itu. Ketika Rasulullah berkata bahwa beliau berpendapat sebagai manusia biasa dan tidak berdasarkan wahyu Ilahi, maka para sahabat tetap mempertahankan pendapat mereka sendiri. Sehingga Rasulullah setuju untuk berperang di medan pertempuran Uhud sesuai dengan keinginan mereka. Pertanyaan para sahabat tentang posisi beliau, ketika menyarankan tindakan tertentu, dan desakan para sahabat demi mempertahankan pendapat mereka sendiri, menunjukkan adanya kebebasan berpendapat yang ditanamkan oleh Nabi di antara para sahabatnya. Lih. Syekh Syaukat Hussain, Hak Asasi Manusia Dalam Islam, (Human Rights in Islam), terj. Abdul Rahim C.N., Gema Insani Press, Jakarta, cet. I, 1996, hlm. 71-73; J. Suyuthi Pulungan, op. cit., hlm. 162

${ }^{18}$ Wafi, op. cit., hlm. 51

19 Wafi, ibid., hlm. 51-52; Pembahasan ini, menurut kami, juga bisa dikaitkan dengan penafiran ilmiah al-Qur'an. Dimana seorang mufassir berusaha membuktikan kemukjizatan al-Qur'an, atau kebenaran-kebenarannya sebagai wahyu Ilahi melalui penafsiran, sesuai dengan perkembangan ilmu pengetahuan, walaupun tidak jarang dirasakan adanya "pemaksaan-pemaksaan" dalam penafsiran tersebut. Hal ini diakibatkan oleh keinginan untuk membuktikan kebenaran ilmiah melalui al-Qur'an, dan bukan sebaliknya. M. Quraish Shihab, Penafsiran Ilmiah al-Qur'an, dalam Membumikan al-Qur'an, Mizan, Bandung, cet. XV, 1997, hlm. 101; atau lebih konkritnya bisa dilihat pada Maurice Bucaille, Bibel, Qur'an dan Sains Modern, (La Bible, Le Coran Et La Science), terj. HM. Rasjidi, Mizan, Bandung, cet. IX, 1992, hlm. 167-221

${ }^{20}$ As-Saidi, op. cit., hlm. 23 
kepada manusia agar mengamati dan berfikir tentang ayat-ayat kauniyyahNya, meliputi langit, bumi, dan seisinya, pergantian malam dan siang, dan kejadian-kejadian yang ada di lautan. Disamping itu, QS. al-Ghasyiyah :1720 bahkan memerintahkan penelitian empiris tentang asal usul atau kejadian unta, tingginya langit, tegaknya gunung, atau bumi yang dihamparkan. Kemudian ada juga hadis Nabi yang memberi kebebasan (berfikir dan berekspresi) untuk menentukan langkah-langkah duniawi kita. Antum a'lamu bi umûri Dun-yâkum. ${ }^{21}$

Selain itu, kebebasan berpikir juga tidak dikhawatirkan oleh Islam. Karena ajaran Islam sendiri tidak bertentangan dengan akal sehat. Oleh karenanya, antara akal dan ilmu pengetahuan harus mempunyai kekuasaan mutlak. Dan Islam mengumandangkan kesesuaiannya dirinya dengan ilmu dan akal. Sehingga ketiganya dapat terpadu untuk kebahagiaan manusia di dunia dan akhirat. ${ }^{22}$

Islam juga tidak membatasi ilmu yang dituntut dengan metode apapun, bahkan dibebaskan apakah nanti bisa tercapai maksud tujuannya atau tidak. Hanya saja Islam membatasi wilayah kekuasaannya pada ilmuilmu agama. Islam mempunyai ajaran-ajaran pokok (nash-nash qath'i) yang harus dijadikan landasan, meskipun dalam hal ini akal juga mempunyai kekuasaan, yaitu ijtihad yang digunakan untuk melakukan istinbath atau menggali hukum nash-nash agama. ${ }^{23}$

Kemudian kebebasan mengemukakan pendapat (burriyyat al-ra'y) merupakan aspek terpenting dari kebebasan berbicara. ${ }^{24}$ Dalam pemerintahan Islam, kebebasan berpendapat adalah hak individu yang mengantarkanya kepada kepentingan dan nuraninya yang tidak boleh dikurangi negara atau ditinggalkan individu. Hal ini penting bagi kondisi pemikiran dan kemanusiaan setiap individu, agar seorang muslim dapat melakukan kewajiban-kewajiban Islamnya. Diantara kewajiban tersebut adalah melakukan amar ma'ruf nahi munkar, yang untuk merealisasikannya membutuhkan dan dituntut kecakapan mengutarakan pendapat secara bebas. $^{25}$

${ }^{21}$ Wafi, op. cit., hlm. 52-55,57

22 As-Saidi, op. cit., hlm. 36

${ }^{23}$ Ibid., hlm. 30

${ }^{24}$ M. Hashim Kamali, Kebebasan Berpendapat dalam Islam, (Freedom of Expression in Islam). terj. Eva Y. Nukman dan Fathiyah Basri, Mizan, Bandung, cet. I, 1996, hlm. 98

${ }^{25}$ Lihat QS. Ali Imran : 104; QS. al-'Ashr : 2-3; QS. al-Taubat : 71. atau hadis Nabi yang menyebutkan bahwa "Barangsiapa di antara kamu melihat suatu kemunkaran, hendaklah ia mengubah dengan tangannya. Jika ia tidak mampu, maka ia ubah dengan lisannya. Dan jika 
Kebebasan berpendapat ini harus dimanfaatkan untuk tujuan menyebarkan kebaikan, dan tidak untuk menyebarluaskan kejahatan dan kezaliman. Seseorang boleh mengemukakan pendapat secara bebas, asalkan tidak melanggar hukum mengenai penghujatan, fitnah, melawan kebenaran, menghina keyakinan orang lain atau dengan mengikuti kemauan sendiri. Dan dalam keadaan bagaimanapun juga Islam tidak akan mengizinkan kejahatan dan kekejian, dan juga tidak memberikan hak kepada siapa pun untuk menggunakan bahasa yang keji atau menghina atas nama kritik. ${ }^{26}$ Oleh karena itu kebebasan berpendapat harus sesuai dengan prinsip kaidah umum hukum Islam, yakni mewajibkan setiap manusia supaya menegakkan dan melaksanakan yang benar, menghapus dan menghindari yang salah. ${ }^{27}$

Prinsip musyawarah dan diskusi-diskusi yang menyertainya, serta hak memilih, menuntut kebebasan berpendapat. Dan al-Qur'an sendiri (QS. al-Syûrâ : 38) membenarkan musyawarah dalam urusan-urusan masyarakat, yang secara esensial terdiri dari pendapat pribadi peserta musyawarah. ${ }^{28}$

Menurut madjid, kebebasan berpikir dan berpendapat, sebagai aktivitas individu, dibedakan antara aktivitas ibadah dan non-ibadah. Jika non-ibadah, seorang muslim dibebaskan berpikir dan berpendapat berdasarkan kaidah fiqhiyyah al-ashl fì ghayr 'ibâdah al-ibâhahah illâ id₹âa mâ dall al-dalîl 'alâ khilâfin (asal di luar ibadah adalah boleh, kecuali jika ada dalildalil agama yang melarangnya). Hal ini menunjukkan bahwa tidak dibenarkan melarang sesuatu jika Allah memperbolehkannya, dan tidak dibenarkan memperbolehkan sesuatu jika Allah melarangnya. Oleh karenanya kebebasan berpikir dan berpendapat dapat dilaksanakan dengan tingkat kebebasan berekspresi yang tinggi. ${ }^{29}$

tidak mampu, maka hendaklah dengan hatinya, dan itu adalah selemah-lemahnya iman.” Lih. Abul A'la Maududi, Hak Asasi Manusia Dalam Islam, (Human Rights in Islam), terj. Achmad Nashir Budiman, Pustaka, Bandung, cet. I, 1985, hlm. 54-55; H.AM. Saefuddin, op. cit., hlm. 15; J. Suyuthi Pulungan, op. cit., hlm. 163-164

${ }^{26}$ Abul A'la Maududi, op. cit., hlm. 53

${ }^{27}$ J. Suyuthi Pulungan, ibid., hlm. 164-165; M. Hashim Kamali, op. cit,hlm. 90; H.AM. Saefuddin, ibid, hlm. 71

${ }^{28}$ M. Hashim Kamali, op.cit., hlm. 92

${ }^{29}$ Nurcholish Madjid, "kata Pengantar" dalam Islam, Doktrin dan Perdaban, Paramadina, Jakarta, cet. IV, 2000, hlm. cvii; Masykuri Abdillah, Demokrasi..., op. cit., hlm. 144; Kebebasan berpikir dengan tingkat kebebasan berekspresi yang tinggi di sini, menurut kami dalam tataran ontologi ataupun epistimologi, yang berkaitan langsung dengan apa dan bagaimana menemukan ilmu pengetahuan. Namun ketika sudah sampai pada tahap aksiologi 


\section{C.2. Kebebasan Beragama}

Sebagaimana diketahui bahwa ajaran agama adalah ajaran yang benar. Meskipun demikian, agama tidak boleh untuk dipaksakan kepada orang lain. Nabi Muhammad SAW. sendiri hanya bertugas menyampaikan risalah dari Allah (muballigh), dan beliau tidak berhak, bahkan tidak bisa, memaksa orang lain untuk percaya dan mengikuti beliau, betapapun benarnya beliau dan ajarannya itu. ${ }^{30}$ Karena persoalan agama merupakan masalah keyakinan, maka tidak seorang pun boleh memaksakan suatu keyakinan terhadap orang lain. Untuk itu, Nabi mempunyai prinsip toleransi beragama; yang secara teknis sering dikaitkan dengan kemerdekaan dan kebebasan beragama (al-burriyyah aldiniyyab). ${ }^{31}$

Ketika Nabi sebagai manusia tergoda untuk memaksakan ajarannya kepada orang lain, Allah pun memperingatkan dengan firmanNya, surat Yunus : $99 .{ }^{32}$ Oleh karena itu, prinsip kebebasan beragama adalah sangat penting dalam tatanan social dan politik manusia. ${ }^{33}$ Gagasan kebebasan, menurut kamali, menuntut diberlakukannya kebebasan memilih bagi setiap orang. Kebebasan beragama, sebagaimana semua kebebasan, pada dasarnya bertindak sebagai pelindung terhadap ancaman penindasan oleh kekuatan yang lebih tinggi. ${ }^{34}$

Menurut wafi, dalam Islam setidaknya ada 3 prinsip dalam kebebasan beragama. Pertama kebebasan meyakini suatu agama dan larangan memaksa beragama. Artinya tak seorang pun dapat dipaksa untuk melepaskan agamanya dan memeluk Islam, sebagaimana termaktub dalam surat al-Baqarah: 256. ${ }^{35} \mathrm{Ke}$ dua, Islam memberi kebebasan untuk diskusi keagamaan. Artinya Islam mensahkan kebebasan individu untuk menyebarkan agama, dengan penjelasan dan

atau penggunaan ilmu tersebut, maka hukum atau pertimbangan rasional dan etikalah yang berbicara, sehingga tidak bisa bebas menurut kehendak oknum tertentu.

${ }^{30}$ Nurcholis Madjid, Islam Kemodernan, dan Keindonesiaan, Mizan, Bandung, cet. IX, 1997, hlm. 56

${ }^{31}$ J. Suyuthi Pulungan, op. cit., hlm. 166

32 "Dan seandainya Tuhanmu menghendaki, tentu berimanlah semua orang yang ada di muka bumi seluruhnya. Maka apakah kamu (hendak) memaksa manusia supaya mereka menjadi orang-orang yang beriman semuanya."

${ }^{33}$ Nurcholish Madjid, loc. cit.

${ }^{34}$ M. Hashim Kamali, op. cit., hlm. 120

35 "Tidak ada paksaan untuk (memasuki) agama (Islam), sesungguhnya telah jelas jalan yang benar dari pada jalan yang salah.” 
alasan yang baik. Oleh karenanya al-Qur'an menuntut kaum muslimin untuk menggunakan kalimah yang lemah lembut dalam mengajak dan menyeru manusia ke dalam Islam. ${ }^{36}$ Ke tiga, iman harus berasal dari kepastian dan keyakinan, bukan dari tradisi atau ikut-ikutan. Inilah sebabnya menurut sebagian ulama tauhid, imannya muqallid, tidak sah. Dan Allah akan menyiksa kaum musyrikin, yang hanya mengikuti dan meniru nenek moyangnya secara membabi buta, tanpa mengetahui dasar-dasarnya dengan mengorbankan kebebasan berpikir dan kepercayaan pribadi. Hal ini sebagaimana yang difirmankan Allah dalam surat al-Baqarah : $170 .{ }^{37}$ Berkaitan dengan ayat ini, wafi merujuk dan sependapat dengan Muhammad Abduh, yang menyatakan bahwa orang yang hanya meniru secara membabi buta, tanpa adanya petunjuk yang benar, tidak termasuk orang yang beriman. Karena seseorang tidak dapat dikatakan beriman kecuali ia memahami agama dan keyakinannya dengan akalnya. ${ }^{38}$

Dalam konteks kebebasan beragama, terdapat perbedaan pendapat tentang seorang muslim yang berpindah ke agama lain (murtad). ${ }^{39} \mathrm{SA}$. Rahman misalnya, dalam The Punishment of Apostasy in Islam, sebagimana disebutkan oleh Kamali, mengatakan bahwa al-Qur'an tidak menyebutkan hukuman murtad adalah kematian. Dan menurutnya, hadis yang menyatakan bahwa siapa saja yang berpindah agama akan dibunuh, ada beberapa kelemahan dalam isnadnya, yang merupakan hadis ahad. ${ }^{40}$ Di samping itu sejarah juga membuktikan bahwa Nabi sendiri atau para sahabatnya tidak pernah memaksa seseorang untuk memeluk Islam, atau menghukum mati seseorang yang hanya karena berpindah keimanannya. ${ }^{41}$ Nabi selalu membiarkan orang-orang munafik yang kafir, setelah mereka beriman. Mereka tidak hanya menyembunyikan

${ }^{36}$ Lih. QS. al-Nahl: 125; QS: al-'Ankabut : 46; QS. al-Baqarah : 111; QS. al-An'am : 148

37 'Dan apabila dikatakan kepada mereka : 'Ikutilah apa yang telah diturunkan Allah', maka mereka menjawab : 'Tidak, tetapi kami hanya mengikuti apa yang telah kami dapati dari nenek moyang kami'. Apakah mereka akan mengikuti juga, walaupun nenek moyang mereka itu tidak mngetahui suatu apapun, dan tidak mendapat petunjuk."

38 Wafi, op. cit., hlm. 38-43; M. Hashim Kamali, op. cit., hlm. 138-139

39 Yakni sikap, yang oleh Thoha Hamim, muncul tidak hanya karena alasan teologis semata, melainkan juga alasan sosiologis. Murtad dipandang dapat membuat seorang mengalami kelimbungan psyhis, karena ia harus merubah kebiasaan yang dibentuk dalam setting nilai agama tertentu, kemudian mengikuti setting nilai agama lain. Thoha Hamim, Islam dan Civil Sociaety dalam Pendidikan Islam, Demokratisasi dan Masyarakat Madani, Fak. Tarbiyyah IAIN Walisongo bekerja sama dengan Pusraka Pelajar, Yogyakarta, cet. I, 2000, hlm. 122

${ }^{40}$ M. Hashim Kamali, op. cit., hlm. 127-128

${ }^{41}$ Loc. cit. 
kekafirannya, tetapi seringkali mereka secara terang-terangan menghina Nabi, yang mengindikasikan kekafiran mereka. Namun demikian, mereka tetap dibiarkan Nabi, dan tidak diberi sangsi. ${ }^{42}$

Menurut as-Saidi, orang murtad yang boleh dibunuh adalah yang memerangi umat Islam. Pada saat itu, orang murtad dianggap memerangi umat Islam, karena umat Islam pada masa Nabi berada dalam keadaan perang. Dan orang-orang murtad tidak tinggal di rumah, tetapi ikut bergabung dengan musuh-musuh Islam, dan ikut menyerang. Sehingga perintah untuk membunuh orang murtad dikarenakan persekutuan mereka pada musuh-musuh Islam. ${ }^{43}$ Sedangkan menurut al-Malyabâriy, orang yang murtad harus dihukum mati, sebagaimana hadis Nabi di atas, yang sebelumnya disuruh bertaubat. ${ }^{44}$

Sekali lagi, penulis menandaskan bahwa Islam, dalam hal ini alQur'an, menyatakan kebebasan beragama sebagai suatu norma dan prinsip Islam, yang tertuang dalam surat al-Baqarah ayat 256. Namun ada sebagian orang yang mengatakan bahwa Islam tidak mengakui kebebasan beragama, dan bahwa ayat-ayat yang membela kebebasan telah di-nasakh oleh ayat lain yang membahas masalah jihad. ${ }^{45}$ Dalam hal ini, as-Saidi mengomentari persoalan tersebut sebagai berikut.

1. tentang Islam disebarkan dengan pedang. Menurutnya dalam Islam tidak ada paksaan untuk memeluknya. Maka satu-satunya jalan bagi mereka adalah mengklaim bahwa nash-nash tersebut telah di-naskh dengan ayat-ayat atau hadis-hadis tentang perang. Menurut mereka, ayat-ayat tersebut diturunkan sebelum umat Islam memiliki kekuatan yang cukup memadai untuk memaksa orang lain memeluk Islam. Karena itulah, orang-orang sebelum itu memeluk Islam tanpa peperangan.

2. tentang nash-nash yang menuntut umat Islam berperang dan jihad di jalan Allah. Menurutnya, mereka menjadikan perang $f i$ sabilillah sebagai sarana untuk memperluas dakwah Islam. Karenanya, ayat-ayat tersebut telah membatalkan nash-nash yang turun sebelumnya. ${ }^{46}$ Padahal perang dalam perspektif Islam bukan untuk memaksa

\footnotetext{
42 As-Saidi, op.cit., hlm. 100

43 As-Saidi, ibid., hlm. 101

${ }^{44}$ Syekh Zain al-Dîn bin 'Abd al-'Azîz al-Malyabâriy, Fath al-Mu'în, Syirkah Nûr Asiyâ, t.t., t,th., hlm. 128

${ }^{45}$ M. Hashim Kamali, op. cit., hlm. 140

${ }^{46}$ As-Saidi, op. cit., hlm. 81-82
} 
manusia memeluk Islam, melainkan melindungi pemeluk Islam dari paksaan orang lain untuk menjadi murtad. ${ }^{47}$

Dan prinsip kebebasan beragama ini, sekarang telah menjadi salah satu dasar yang diundangkan oleh berbagai negara dalam konstitusinya. Prinsip ini juga termaktub dalam Declaration of Human Rights (1948) pasal 18 dan Covenant on Civil and Political Right (1966) pasal 18 yang dikeluarkan oleh PBB. ${ }^{48}$ Sehubungan dengan ini, Husain Haikal, kebebasan beragama, yang juga tertuang dalam perjanjian atau dokumen politik antara kaum muslimin (muhajirin dan anshar) dengan orang-orang yahudi, merupakan pintu baru dalam kehidupan politik dan peradaban dunia pada masa itu. ${ }^{49}$

\section{C.3. Kebebasan Berpolitik dalam Islam}

Menurut Islam, pemerintah yang ada ini adalah wakil-wakil (khalifah) dari yang Maha Pencipta, dan tanggung jawabnya tidak dipercayakan kepada seorang individu, keluarga atau masyarakat tertentu, tetapi seluruh umat Islam. Seperti dinyatakan dalam QS. al-Nûr : $55 .^{50}$ Hal ini menunjukkan bahwa kedudukan khalifah adalah anugrah kolektif dari Allah, dimana kedudukan seorang individu muslim tidaklah lebih tinggi atau lebih rendah dari muslim lainnya. ${ }^{51}$ Maka tepat jika kebebasan berpolitik, menurut Wafi dan as-Saidi, adalah bahwa rakyat atau umat merupakan pemegang dan sumber segala kekuasaan. Umat mempunyai hak untuk berpartisipasi dalam menentukan kekuasan sesuai dengan kehendaknya yang harus dijalankan. ${ }^{52}$

\footnotetext{
${ }^{47}$ Loc. cit.

${ }^{48}$ Isi dari kedua pasal tersebut substansinya hampir sama, terutama yang menyebutkan adanya kebebasan beragama. Yakni; " setiap orang berhak atas kebebasan pikiran, keinsyafan bathin dan agama; dalam hal ini termasuk bebasan berganti agama....."(Declaration of Human Rights , pasal 18). Lih. Prof. Miriam Budiardjo, Dasar-Dasar Ilmu Politik, Gramedia, Jakarta, cet. V, 1980, hlm. 132; Berkaitan dengan kata kebebasan yang ada dalam pasal 18 tersebut, menurut Fatima Mernissi, kata yang paling tepat untuk menerjemahkannya adalah syirk. Syirk yang berarti bergabung bersama atau ikut berperan serta, digunakan untuk menggambarkan kekacauan yang mendahului fath makkah $630 \mathrm{M}$. Karena pasal ini merupakan definisi yang tepat menyangkut jahiliyyah, dunia pagan praIslam yang kacau. Fatima Mernisi, Islam and Democracy Fear of the Modern World, Addison Wesley Publising Company, USA, 1994, hlm. 85-87

${ }^{49}$ Muhammad Husain Haekal, op. cit., hlm. 205; J. Suyuthi Pulungan, op. cit., hlm. 169

50 "Allah telah berjanji untuk mengangkat orang-orang yang beriman dan beramal shaleh di antaramu sekalian untuk dijadikan sebagai wakil-wakil-Nya di bumi...."

${ }^{51}$ Abu A'la Maududi, op. cit., hlm. 67-68

${ }^{52}$ Wafi, op. cit., hlm. 62; as-Saidi, op. cit., hlm. 41
} 
Jika umat merupakan pemegang kekuasaan, maka pemerintah di bawah kekuasaannya, dan bukan sebaliknya. Oleh karenanya umat mempunyai kebebasan politik penuh, yang diberikan oleh Islam, ${ }^{53}$ bukan hak yang diberikan oleh penguasa. ${ }^{54}$

Dalam hal ini, setidaknya ada dua hak yang paling dominan untuk seluruh umat, yakni hak memilih pemimpin dan hak mengawasi dan mengontrol setiap tindakan pemimpinnya, baik secara langsung atau dengan perwakilan.

\section{C.3.a. Hak memilih Pemimpin}

Menurut ijma' sahabat, Islam memberikan hak kepada umat manusia untuk memilih pemimpin tertingginya yang mengawasi badan eksekutif, yakni khalifah. ${ }^{55}$ Hanya saja mekanisme pemilihan tersebut berbeda dengan cara yang berlaku dalam pemerintahan republik demokrasi modern, (yang tidak akan penulis singgung di sini), walaupun intinya sama. Menurut Islam, pemilihan pemimpin ini dipercayakan kepada ablul hall wal 'aqd (dewan legislative), yang terdiri dari para tokoh Islam, ualama fiqh, ketua-ketua suku, kepala wilayah, dan orang-orang yang punya pengaruh. ${ }^{56}$

Dalam istilah politik Islam dikenal kata bai'at atau janji setia. Dimana seseorang berjanji menyerahkan penyelesaian persoalannya dan persoalan orang Islam seluruhnya kepada pemimpinnya. Menurut Ibn Khaldun, yang disebutkan oleh Wafi, pada saat mengesahkan janjinya, ia meletakkan tangannya di atas tangan pemimpinnya, untuk lebih menyakinkan perjanjian itu. Dan kekhalifahan ini dianggap sah dengan pembai'atan sebagian besar ablul halli wal 'aqd. Jika ada kelompok minoritas yang tidak setuju atau punya pendapat lain, hal ini tidak berpengaruh apa-apa. Dengan demikian, dalam Islam memberi hak mutlak kepada umat untuk ikut berpartisipasi dalam memilih pemimpin

\footnotetext{
${ }^{53}$ Berkaitan dengan persoalan kebebasan politik ini, memang harus kita akui, bahwa tidak ditemukan nash yang jelas, baik dari al-Qur'an atau Hadis, yang menetapkan hak ini, penegaknya, atau aturan mainnya. Namun bukan berarti Islam tidak menggariskan prinsipprinsip yang jelas dalam masalah politik. Karena sumber ajaran ini tidak hanya dati alQur'an dan Hadis, tetapi juga dari ijma' (consensus ulama). Dalam hal ini ijma' yang terkuat dan tertinggi tingkatannya adalah ijma' sahabat pada masa khulafaur rasyidin. Dimana mereka menampilkan prinsip-prinsip Islam dalam sisitem pemerintahan dan politiknya. Wafi, loc. cit.

54 As-Saidi, ibid., hlm. 42.

55 A.M. Saefuddin, op. cit., hlm. 17; Wafi, op. cit., hlm. 63

${ }^{56}$ Wafi, ibid., hlm. 64
} 
tertingginya, khalifah yang mengawasi seluruh badan eksekutif. Dan Islam menetapkan seseorang tidak berhak menyandang gelar khalifah, kecuali atas pilihan rakyat. ${ }^{57}$

\section{C.3.b. Hak Mengawasi dan Mengontrol Pemerintah}

Bagian dari kebebasan berpolitik adalah melakukan kritik (burriyyah al-mu'âradhah atau burriyyah naqd al-hakêm) dan memantau kegiatan pemerintah, ${ }^{58}$ yang juga untuk mendukung amar ma'ruf nahi munkar. Dimana rakyat berhak mengawasi pemimpinnya dan mengoreksi setiap tindakannya. Dan hal semacam ini sudah pernah dilaksanakan dan dicontohkan oleh para pendahulu kita. ${ }^{59}$

Untuk melakukan kritik yang benar, setidaknya ada tiga syarat yang harus dipenuhi. Pertama, ada fakta-fakta yang memperkuat dan latar belakang yang pasti untuk mendasari kritik. ${ }^{60} \mathrm{Ke}$ dua, pengkritik harus yakin tentang kebenaran moral dari pendapatnya. Karena ia tidak boleh mengatakan sesuatu, kecuali jika dia yakin bahwa apa yang dikatakannya adalah benar. Ke tiga, kritik harus sesuai dan tepat sasaran. Kata-kata yang digunakan dan cara mengkritik disesuaikan dengan situasi (tidak boleh terlalu keras atau terlalu lunak, tetapi harus sopan dan efektif). ${ }^{61}$

Dari realitas empirik politik pada masa Islam awal, menurut Robert $\mathrm{N}$, Bellah, seorang sosiolog agama terkemuka, sebagaimana diungkapkan oleh Madjid, masyarakat Islam yang paling dini itu (masa Nabi dan 4 khalifah) adalah modern. Dia berasumsi demikian, karena melihat tingkat partisipasi politik Islam yang terbuka dan tinggi dari seluruh lapisan masyarakat. Disamping itu, keterbukaan dan kemungkinan posisi pimpinan masyarakat untuk diuji kapabilitasnya, berdasarkan ukuran-

\footnotetext{
${ }^{57}$ Ibid., hlm. 64-65

${ }^{58}$ Umat Islam mempunyai hak untuk memprotes tirani pemerintah. Al-Qur'an dalam hal ini menyatakan "Allah tidak menyukai ucapan buruk, kecuali dari orang yang dianiaya...”(QS. al-Nisa' :148). Artinya Allah mencela kutukan-kutukan atau ucapanucapan buruk yang keras. Namun bagi mereka yang menjadi korban ketidakadilan, Allah memberikan hak kepada mereka untuk melakukan protes. Abu A'la Maududi, op. cit., hlm. 52

59 Abu bakar misalnya, ketika berpidato saat pelantikannya, setelah terpilih menjadi khalifah. Dia mengatakan:'Wahai kaumku, aku telah diercayai untuk memerintah kalian, tetapi aku bukanlah yang terbaik di antara kalian. Bantulah aku jika aku benar, dan ingatkan aku jika aku salah." Ungkapan ini juga menunjukkan adanya kebebasan mengemukakan pendapat atau melakukan kritik kepada penguasa atau pemerintah. Mohammad Hashim Kamali, op. cit., hlm. 75-76

${ }^{60}$ QS. al-Hujurat : 6

${ }^{61}$ M. Hashim Kamali, op.cit., hlm.79-83
} 
ukuran yang universal, yang dilambangkan dalam usaha melembagakan kepemimpinan, tidak berdasarkan warisan atau keturunan, tetapi berdasarkan pemilihan (sesuai dengan mekanisme yang ada pada masa itu). ${ }^{62}$

\section{4. Kebebasan Ekonomi dalam Islam}

Menurut pandangan Islam, bahwa alam jagat raya ini dan seisinya adalah diperuntukkan manusia, ${ }^{63}$ baik yang berupa tumbuh-tumbuhan, batu, air, ataupun potensi-potensi alam lainnya. Sebagai makhluk yang menyandang gelar khalifah, ${ }^{64}$ manusia mempunyai tugas untuk melindungi, melestarikan, mengamankan, mengembangkan segala potensi alam yang ada, sekaligus menggunakannya.

Dalam menggunakan potensi alam ini, manusia dapat melakukan cocok tanam, transaksi perdagangan, atau mengeluarkan sumber alam bumi yang berupa pertambangan, ${ }^{65}$ dengan seluas-luasnya. Di samping itu Islam juga memperingatkan kepada mereka agar menggunakan potensi alam yang ada secara proporsional, tidak terlalu mengeksploitasi. Karena al-Qur'an sendiri telah menyatakan bahwa segala kerusakan yang ada di daratan ataupun lautan adalah disebabkan oleh keserakahan manusia. ${ }^{60}$ Kemudian dalam melakukan proses kegiatan ekonomi tersebut, seseorang tidak bisa lepas dengan aturan-aturan yang sudah ada dalam Islam. Dengan demikian Islam sangat apresiasif terhadap kegiatan ekonomi, dan memberikan kesempatan berekonomi selebar-lebarnya terhadap umatnya. Hal ini setidaknya dapat dibuktikan dalam banyak ayat al-Qur'an yang selalu menggandeng ayat perintah melaksanakan shalat dengan menunaikan zakat. Dan orang yang dapat menunaikan zakat adalah orang yang secara ekonomis telah mapan.

\section{Kesimpulan}

Konsep kebebasan (al-burriyyah atau liberty) dalam Islam, asal mulanya adalah konsep ikbtiyar dan taqdir, yang berkaitan dengan kebebasan atau tidaknya manusia dalam melakukan perbuatannya, dalam term teologi atau agama. Kemudian setelah terjadinya kontak dengan

\footnotetext{
${ }^{62}$ Nurcholish Madjid, Islam, Doktrin....., op. cit., hlm. 559

${ }^{63}$ Lih. QS. al-Baqarah : 29. "Dan Dialah Allah yang telah menjadikan segala sesuatu di bumi untuk kalian semua........".

64 QS. al-Baqarah : 30. "Dan ketika Tuhanmu berkata kepada malaikat bahwa sesungguhnya Aku telah menjadikan khalifah di bumi....."

${ }^{65}$ Syekh Musthafâ al-Ghalâyanî, op. cit., hlm. 92

${ }^{66}$ Lih. QS. al-Rum : 41
} 
dunia barat konsep tersebut berkembang menjadi lebih luas cakupannya. Seperti kebebasan berekspresi atau mengemukakan pendapat, berfikir, kebebasan berpolitik atau kebebasan ekonomi. Walaupun dapat dikatakan bahwa ide-ide dasar atau embrio pemikiran kebebasan di atas sudah ada dalam Islam, namun secara konseptual pada masa lalu belum ada. Baru pada abad sebelum 18, al-Farabi mengemukakan konsep al-Ahrâr dalam kitab al-Siyâsah al-Madaniyyah. ${ }^{67}$

Kemudian konsep kebebasan individual seseorang dalam Islam, sebagaimana yang telah penulis jelaskan terdahulu, ternyata tidak bisa berjalan sendirian, tanpa dibarengi dengan kewajiban-kewajiban lain yang harus dijalankan, termasuk mempertimbangkan kepentingan orang lain. Dari sinilah tampak kebebasan seseorang dibatasi oleh kebebasan orang lain. Sebagaimana tergambar dalam sebuah ungkapan " $\underline{H}$ urriyyat al-mar'i mahdûdah bi hurriyat siwâhu." 68

Maka semangat saling menghormati dan saling menghargai yang sejati, dalam konteks kebebasan beragama, berpendapat, berpikir atau politik, adalah pangkal adanya pergaulan kemanusiaan dalam system sosial dan politik yang demokratis. Dan semangat dimaksud menuntut adanya sikap toleransi, tenggang rasa, dan keserasian hubungan sosial. ${ }^{69}$ Sehingga dapat dinyatakan di sini, bahwa kebebasan dalam Islam lebih terbatas dan terarah, atau dengan kata lain bebas tapi terikat. Hal ini setidaknya bisa dilihat pada demokrasi liberal dan Islam. Dimana demokrasi liberal menekankan kemampuan berbuat tanpa batas; sedang dalam Islam, kebebasan menekankan kemampuan untuk bereksis. Karena standar hukumnya berbeda. Jika hukum dalam demokrasi liberal dengan mudah diubah atau diganti dengan hukum baru yang lebih akomodatif terhadap aspirasi rakyat, untuk mendapatklan kebebasan yang lebih besar. Sementara hukum Islam tidak bisa berubah seenaknya. Hanya produk hukum Islam dari hasil ijtihad saja yang dapat diubah, sedangkan hukumhukum dari nash-nash qath'i tidak boleh dirubah. ${ }^{70}$

\footnotetext{
${ }^{67}$ Masykuri Abdillah, Kuliah Islam dan Peradaban Global, tgl 28-10-2001, PPs IAIN WS.

${ }^{68}$ Nurcholish Madjid, Islam, Doktrin....., op. cit., hlm. 566-567

${ }^{69}$ Nurcholish Madjid, Islam, kemodernan,....., op. cit., hlm. 58-59

70 Berkaitan dengan ijtihad lebih lanjut bisa dilihat pada Fazlur Rahman, Islamic Methodology in History, Adam Publishers \& Distributors, Shandar Market, Chitli Qabar, Delhi, India, 1994, bab. IV dan V, hlm. 149-190; atau Sayyid Muhammad Musa Tawana, alIjtihad, Dar al-Kutub al-Haditsah, Beirut, t.t.
} 


\section{DAFTAR PUSTAKA}

Bucaille, Maurice, Bibel, Qur'an dan Sains Modern, (La Bible, Le Coran Et La Science), terj. HM. Rasjidi, Mizan, Bandung, cet. IX, 1992

Budiardjo, Miriam, Dasar-Dasar Ilmu Politik, Gramedia, Jakarta, cet. V, 1980

Al-Ghalâyanî, Musthafâ, Syekh, Tdhah al-Nâsyi'în Kitâb akhlâq wa adâb wa Ijtimấ, Maktabah Raja Murah Pekalongan, Pekalongan, t.t.

Gibb, H.A.R., et. al., The Encyclopaedia of Islam, E.J. Brill, Leiden, 1960

Haekal, Muhammad Husain, Sejarah Hidup Mubammad, (Hayat Muhammad) terj. Ali Audah, Litera Antar Nusa, Jakarta, cet. XVI, 1992

International Encyclopedia of the Social Sciences, The Macmillan Company and The Free Press, New York, Collier - Macmillan Publishers, London, 1972

Kamali, Mohammad Hashim, Kebebasan Berpendapat dalam Islam, (Freedom of Expression in Islam) terj. Eva Y. Nukman dan Fathiyah Basri, Mizan, Bandung, cet. I, 1996

Machasin, Menyelami Kebebasan Manusia, Pustaka Pelajar, Yogyakarta, cet. I, 1996

Madjid, Nurcholis, Islam Kemodernan, dan Keindonesiaan, Mizan, Bandung, cet. IX, 1997

---------, Islam Doktrin dan Peradaban, Paramadina, Jakarta, cet. IV, 2000

Masykuri Abdillah, Demokrasi di Persimpangan Makna : Respons Intelektual Muslim Indonesia terhadap Konsep Demokrasi, (Responses of Indonesian Muslim Intellectuals to the concept of Demokracy) (1966-1993), terj. Wahib Wahab, Tiara Wacana, Yogya, cet. I, 1999

----------, Theological Responses to the Concept of Democracy and Human Rights: The Case of Contemporary Indonesia Muslim Intellectuals, Studia Islamika, Vol. 3, No. 1, IAIN Syarif Hidayatullah, Jakarta, 1996

Maududi, Abul A'la, Hak Asasi Manusia Dalam Islam, (Human Rights in Islam), terj. Achmad Nashir Budiman, Pustaka, Bandung, cet. I, 1985

Al-Malyabâriy, Zain al-Dîn bin 'Abd al-'Azîz, Syekh, Fath al-Mư̂̀n, Syirkah Nûr Asiyâ, t.t., t,th

Mernisi, Fatima, Islam and Democracy Fear of the Modern World, Addison Wesley Publising Company, USA, 1994

Mulkhan, Abdul Munir, Mencari Tuban dan Tujuh Jalan Kebebasan (Sebuah Esai Pemikiran Imam al-Ghazali), Bumi Akasara, Jakarta, cet. I, 1992

Nasution, Harun, Teologi Islam, UI-Press, Jakarta, cet. V, 1986

Rahman, Fazlur, Islamic Methodology in History, Adam Publishers \& Distributors, Shandar Market, Chitli Qabar, Delhi, India, 1994 
Saefuddin, A.M.H, Ijtihad Politik Cendikiawan Muslim, Gema Insani Press, Jakarta, cet. I, 1996

As-Saidi, Abd al-Mutaal, Kebebasan Berpikir dalam Islam, (uuriyyat al- Fiker Fî al-Islâm), terj. Ibnu Burdah, Adi Wacana, Yogyakarta, cet. I, 1999

Shihab, M. Quraish, Penafsiran Ilmiah al-Qur'an, dalam Membumikan al-Qur'an, Mizan, Bandung, cet. XV, 1997

Suseno, Franz Magnis, Etika Dasar, Kanisius, Yogyakarta, cet. VII, 1997

---------, Demokrasi Sebagai Proses Pembebasan : Tinjauan Filoofis dan Historis, dalam Agama dan Demokrasi, P3M bekerjasama dengan Friedrich Nauman Stiftung (FNS), Jakarta, cet. I, 1992

Suyuthi Pulungan, MA.,J., Prinsip-Prinsip Pemerintahan Dalam Piagam Madinah ditinjau dari Pandangan al-Qur'an, Raja Grafindo Persada, Jakarta, cet. II, 1996

Syaukat Hussain, Syekh, Hak Asasi Manusia Dalam Islam, (Human Rights in Islam), terj. Abdul Rahim C.N., Gema Insani Press, Jakarta, cet. I, 1996

Thoha Hamim, Islam dan Civil Sociaety dalam Pendidikan Islam, Demokratisasi dan Masyarakat Madani, Fak. Tarbiyyah IAIN Walisongo bekerja sama dengan Pusraka Pelajar, Yogyakarta, cet. I, 2000

Wafi, Ali Abdul Wahid, Kebebasan Dalam Islam (al-Hurriyat Fi al-Islâm), terj. H. S. Agil Husin al-Munawaw, dan Lukman Hakim Zainuddin, Dina Utama Semarang (Toha Putra Group), t.th

Wahid, Abdurrahman, H., Sosialisasi Nilai- Nilai Demokrasi, dalam Agama, Demokrasi dan Trasformasi Sosial, Edit. M. Masyhur Amin dan Mohammad Najib, LPKSM NU DIY, Yogyakarta, cet. I, 1993

Watt, Montgomery. W., Islamic Philosophy and Theology, Edinburgh University Press, Amerika, 1979 